\title{
ESTIMATING PROBABILITY OF FAULTS OCCURRING IN TRUCKS
}

\author{
Agnieszka Kupiec ${ }^{1 *}$, Jerzy Kupiec ${ }^{2}$ \\ ${ }^{1}$ Poznan University of Technology, Institute of Machines and Motor Vehicles, Piotrowo 3, 60-965 Poznań, Polska, \\ email:agnieszka.kupiec@put.poznan.pl \\ ${ }^{2}$ Poznan University of Technology, Institute of Machines and Motor Vehicles, Piotrowo 3, 60-965 Poznań, Polska, \\ email: jerzy.kupiec@put.poznan.pl \\ ${ }^{*}$ Corresponding author
}

Reviewed positively: 14.01 .2020

Information about quoting an article:

Kupiec A., Kupiec J. (2020). Estimating probability of faults occurring in trucks. Journal of civil engineering and transport. 2(1), ISSN 2658-1698, e-ISSN 2658-2120, 47-54, DOI: 10.24136/tren.2020.004

\begin{abstract}
This paper discusses the matter of fault detection by the diagnosticians of a Regional Vehicle Inspection Station (RVIS) in trucks. The analysis data were obtained directly from RVIS. The produced results were presented as bar graphs indicating the trend change from 2014 to 2018. Thus obtained trends were described by formulae and used to calculate the probability of a fault from the analysed group appearing. The obtained data dependency can be used to calculate the probability of a fault appearing in a truck during a year of operation.
\end{abstract}

Key words - fault, truck, technical inspection, RVIS

JEL Classification - R4, R41

\section{INTRODUCTION}

The faults of motor vehicles are a constant feature of their use. This also translates into the number of road accidents worldwide, as indicated by the authors of the publications [1-4]. Apart from the obvious causes of accidents, such as violation of road traffic rules by drivers and pedestrians (excessive speed and overload, drunk driving) or poor quality of road infrastructure, the technical faults of vehicles should also be taken into account. The reasons for technical failures can be the failure of parts, components and assemblies caused by aging, poor quality or non-observance of technological standards when they are implemented.

Whilst moving cargo from the place of loading to the recipient, one needs the most faultless vehicle possible in order to avoid any losses incurred by its downtime. One of the factors that may limit vehicle downtime to minimum is periodic inspection at a vehicle inspection station. Therefore, the results of such inspections on trucks have been analysed in the paper. Based on the results of the analysis, the probability of a fault occurring in a used vehicle was calculated. As statistical data indicate, the number of vehicles operating on our roads increases annually. In the year 2014, 26472274 motor vehicles were registered, 3037427 of them were trucks. In the year 2017 this number increased to 29149178 motor vehicles and 3212690 trucks [5]. It was a global increase, thus the number of trucks remains in the constant ratio of $11 \%$ motor vehicles. The vehicles registered vary from new to used, of different age as well as degree of technological advancement.

\section{BASIC TERMS}

At the beginning, it's important to define the basic terms used further in the paper, such as: probability, fault, truck, periodic technical inspection. The available literature usually interprets probability as the possibility of occurrence of a given event, where the expected result of the event is a matter of chance alone. In mathematics, the concept of probability is defined as a function that measures families of sets of chance events that are used to describe frequency or certainty of occurrence of a specific event [6] Thus, probability is defined for the further part in the paper as the percentage of faults that occurred during vehicle inspection and appeared during the examination in a Regional Vehicle Inspection Stations in a given time period. 
Another term that requires elaboration and is defined in traffic regulations is the term truck. It is a motor vehicle designed for transportation of cargo. This term also refers to a vehicle designed for transportation of cargo as well as from 4 to 9 persons including the driver [7]. According to the legal regulations (art. 66), a vehicle operating on national roads should undergo a periodic technical inspection and be properly maintained in order to ensure safety of its passengers and other road users, low exhaust emissions, proper operation of the vehicle, an appropriate level of noise, sufficient visibility for the driver and acceptable level of radioelectric emissions. The said criteria can be verified by various institutions such as: the Police, Road Transport Inspectorate, workshops, drivers themselves (in a very limited scope if they have the professional knowledge and appropriate equipment), dealerships and Vehicle Inspection Stations (Regional Inspection Stations for vehicles of the GVW exceeding 3.5 tons or Basic Inspection Stations for the vehicles of the GVW up to 3.5 tons). Most frequently drivers have their vehicles inspected at the last two. However, only the Vehicle Inspection Stations can conduct a technical inspection of a vehicle that is entered into the vehicle registration certificate. It is required for the vehicle to remain road legal. Therefore, ensuring a technical inspection of a vehicle is the responsibility of a vehicle owner.

The term "fault" is considered basic and should be comprehensible to everyone, however finding an unequivocal definition is not as simple. Most frequently, it is defined as: a discrepancy between a computed, observed, or measured value or condition and the true, specified, or theoretically correct value or condition, a deviation from the required operation of system or subsystem, the state of an item characterized by inability to perform a required function, the termination of the ability of an item to perform a required function (always related to a required function). Some also define fault as a small flaw or inefficiency of a process [8]. Irrespective of the name, faults are detected by diagnosticians during periodic technical inspections. A diagnostician assesses the condition of a vehicle based on his/her professional knowledge and follows the guidelines of fault assessment as stated in column IV of appendices 1 and 2 of the regulation of scope and methods of conducting vehicle technical inspections [9]. In the end, it is the diagnostician who decides if the vehicle is road legal.

\section{THE RESULTS OF THE INSPECTIONS}

As mentioned in the introduction, the research was based on the data obtained from Regional Vehicle Inspection Stations. The acquisition of the data was very difficult since the generally available data as regards inspections conducted at Vehicle Inspection Stations (SKP) are not divided into vehicle categories, which makes it impossible to distinguish trucks from other types of vehicles. However, on the website of Central Register of Vehicles and Drivers (CEPiK) there is a bookmark 'Vehicle Inspection Stations and the technical inspections in the year 2018'. The information provided in the bookmark shows the number of Basic and Regional Vehicle Inspection Stations and the number of inspections performed by these stations in a given year. The information includes passing and failing vehicles [10]. The Vehicle Inspection Stations provide CEPiK with very vague information. Therefore, it was necessary to approach Regional Vehicle Inspection Stations directly and inquire how many trucks had been inspected in the subsequent years and how many of them had had faults detected and what kind of faults had been found. It turned out that some of the Regional Vehicle Inspection Stations conducted almost no inspections of such vehicles, or were unwilling to share the data out of concern for data security or out of fear of leaking information to competition. Given the above, the analysis used the data of 10 Regional Vehicle Inspection Stations that agreed to share the information. The obtained data were averaged for all the stations and contrasted separately for every year of the investigated period. According to the data, on average, each of the investigated stations conducted inspections of almost 7500 different vehicles per year, from passenger cars through trailers, semi-trailers, motorbikes, trucks, tractor units, to trackless trains. Trucks were $10 \%$ of the vehicles controlled by those stations. Figure 1 shows the distribution of the trucks inspected by Regional Vehicle Inspection Stations in specific years.

It shows a downward trend of the number of vehicles inspected throughout the years. Between the years 2014 and 2018 this decrease was $32 \%$. The average age of the trucks undergoing a periodic technical inspection in the years 2014 2018, oscillated between 10 and 20 years.

A periodic technical inspection detects faults that, depending on the level of traffic hazard, are classified as minor, significant or posing a direct 
safety hazard. The faults that are significant or posing a direct safety hazard lead to a failure to obtain a road-legal status of a vehicle and the vehicle needs to undergo a repair. Each Regional Vehicle Inspection Station showed a certain percentage of inspections that ended with a failing result, as shown in Figure 2 . There was a noticeable and alarming trend of increase in the failing inspections despite the yearly decrease of the number of inspections. In the year 2014 they constituted $1.2 \%$ whereas in the year 2018 they constituted as much as $4.7 \%$ of the inspections.

When analysing the causes of the failing results of vehicle inspections, it was possible to determine the nature of the detected faults and their occurrence in the investigated period. It was however necessary to start from determining the scope of the inspection conducted by the Regional Vehicle Inspection Station.

During a technical inspection, the diagnostician examines the documentation as well as the condition of the vehicle components and systems.
The scope of such a formal vehicle inspection involves inter alia:

a. Identifying the vehicle through verifying the vehicle identification number, determining and comparing the compatibility of the entry in the certificate with the factual vehicle data, the correctness and condition of the license plates;

b. Verifying the vehicle additional equipment;

c. Verifying and evaluating the operation of specific components and systems, particularly those responsible for driving safety and environmental performance. The elements undergoing the verification and evaluation are:

- the brake system;

- the steering;

- visibility;

- lights and electrical equipment;

- axles, wheels, tyres, suspension

- chassis and elements attached to it;

- other equipment:

- inconvenience;

- other conditions to be evaluated.

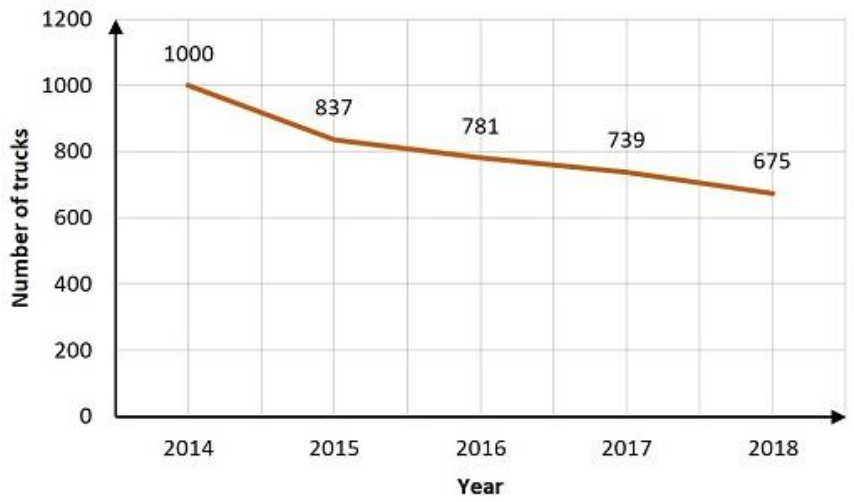

Fig. 1. Average number of trucks inspected by Regional Vehicle Inspection Stations in the years 2014-2018

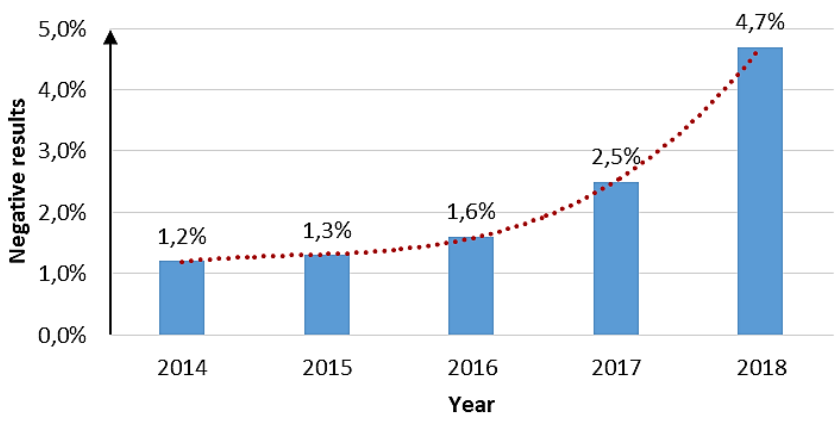

Fig. 2. Failing inspection results in relation to the number of trucks inspected by the Regional Vehicle Inspection Stations in the years 2014-2018 


\section{Estimating probability of faults occurring in trucks}

Table 1. The amount of faults in areas not related to the technical condition of the vehicle in [\%]

\begin{tabular}{|l|c|c|c|c|c|c|}
\hline Investigated areas & $\mathbf{2 0 1 4}$ & $\mathbf{2 0 1 5}$ & $\mathbf{2 0 1 6}$ & $\mathbf{2 0 1 7}$ & $\mathbf{2 0 1 8}$ & Average \\
\hline Vehicle identification & 11.4 & 10 & 11.2 & 9.8 & 10.3 & 10.5 \\
\hline Other additional conditions & 0.0 & 0.0 & 0.7 & 0.5 & 0.3 & 0.3 \\
\hline Other equipment & 2.4 & 5.7 & 7.7 & 4.1 & 7.3 & 5.4 \\
\hline
\end{tabular}

Table 2. The amount of technical faults detected during an inspection throughout specific years in [\%]

\begin{tabular}{|l|c|c|c|c|c|c|}
\hline The inspected component & $\mathbf{2 0 1 4}$ & $\mathbf{2 0 1 5}$ & $\mathbf{2 0 1 6}$ & $\mathbf{2 0 1 7}$ & $\mathbf{2 0 1 8}$ & Average \\
\hline Brake system & 53.7 & 57.1 & 69.9 & 63.4 & 57.3 & 60.3 \\
\hline Steering & 20.3 & 15.7 & 20.3 & 13.4 & 17.6 & 17.5 \\
\hline Visibility & 5.7 & 7.9 & 9.8 & 3.1 & 4.5 & 6.2 \\
\hline Lights and electric equipment & 25.2 & 45.0 & 43.4 & 29.9 & 25.5 & 33.8 \\
\hline Axles & 0.8 & 0.7 & 1.4 & 0.5 & 1.5 & 1.0 \\
\hline Wheels & 2.4 & 0.7 & 3.5 & 2.1 & 2.7 & 2.3 \\
\hline Tyres & 8.9 & 12.1 & 8.4 & 8.2 & 7.6 & 9.1 \\
\hline Suspension & 27.6 & 30.7 & 29.4 & 34.0 & 31.8 & 30.7 \\
\hline Chassis and the elements attached to it & 12.2 & 22.9 & 23.8 & 10.8 & 20.0 & 12.4 \\
\hline Inconvenience & 23.6 & 32.1 & 19.6 & 18.0 & 14.2 & 21.4 \\
\hline
\end{tabular}

The obtained data were divided into two groups based on the above-mentioned scope of technical inspection, one containing the faults that are not directly related to the technical condition of a vehicle and the other containing the faults that directly impact the vehicle condition. The results have been compared in tables 1 and 2 .

Table 1 shows the results of the part of the inspection not directly related to the technical condition of the vehicle, but its identification and equipment. It was observed that, on average, $10.5 \%$ of the failing results had been caused by problems during the identification process, $5.4 \%$ by lacking or inoperative additional equipment and $0.3 \%$ by additional conditions not being met.

The faults related directly to the vehicle technical condition were compared in table 2 . In order to better portray the distribution of problems from the group 'axles, wheels, tyres, suspension', it was divided into several subgroups.

In rough evaluations, one may use averaged values for a given time period as was shown in the last column of table 2 . The analyses have shown that the most frequently failing system in a truck was the brake system. It was found inoperative in $60.3 \%$ of the inspected vehicles. Faults related to lights and the electrical equipment occurred in $33.8 \%$ of the cases, faults of suspension occurred in $30.7 \%$ and inconvenience in $21.4 \%$. The first three were marked red as most significant in table 2 .

The problems with the vehicle steering occurred, on average, in $17.5 \%$ of the cases, the problems with the chassis and the components attached to it in $12.4 \%$, and the faults related to the visibility and other inspected components occurred in less than $10.5 \%$ of cases.

Upon analysing the results, the probability of failing a technical inspection of a truck was described by the trend line from Figure 2 :

$$
y=0.0034 x^{2}-0.0121 x+0.0218
$$

The trendline equation was generated by the Microsoft Excel spreadsheet. By extrapolating from the obtained values to 2019, the probability of a vehicle failing a technical inspection could be calculated at $7.2 \%$.

When analysing the faults in trucks in the period of five years, it is clear that their number was not constant. Therefore, a function is needed to describe the probability of their occurrence. This provides a way to gain information about the 

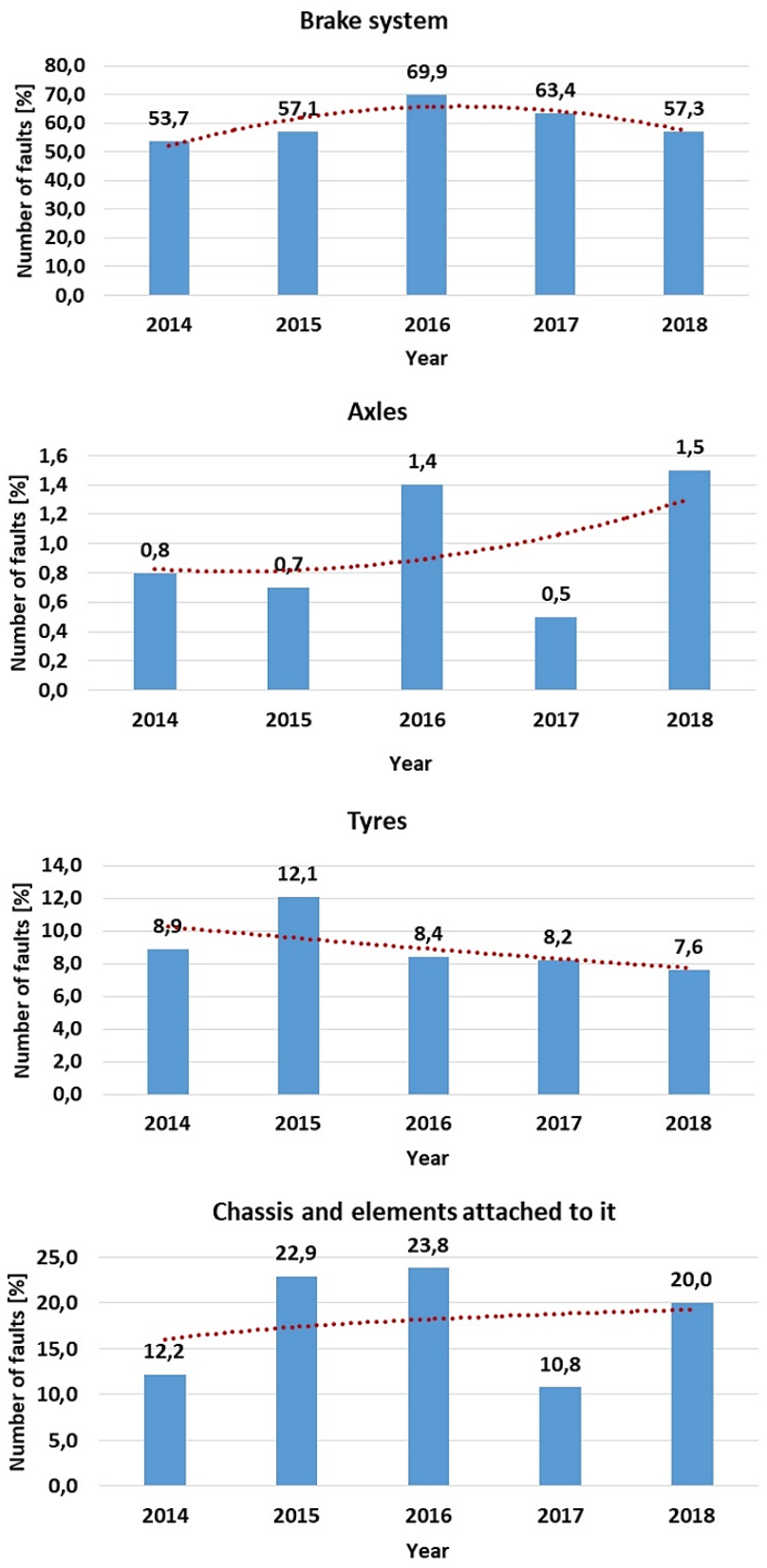

Fig. 3. The most frequently failing systems in trucks

distribution of faults in the following years. Figures 3 and 4 compare the changes in the percentage of faults of a given system or component in given years with an emphasis on the trendline describing the changes. The functions describing specific trends have been compared in table 3 . 
It is clearly visible that majority of the fault distributions can be described by trendline equations, but those concerning visibility and lighting with electrical equipment have to be considered differently. The analysis of changes in the case of visibility yielded a significant decrease in the number of faults in the year 2017 and then an increase in the following year. The research
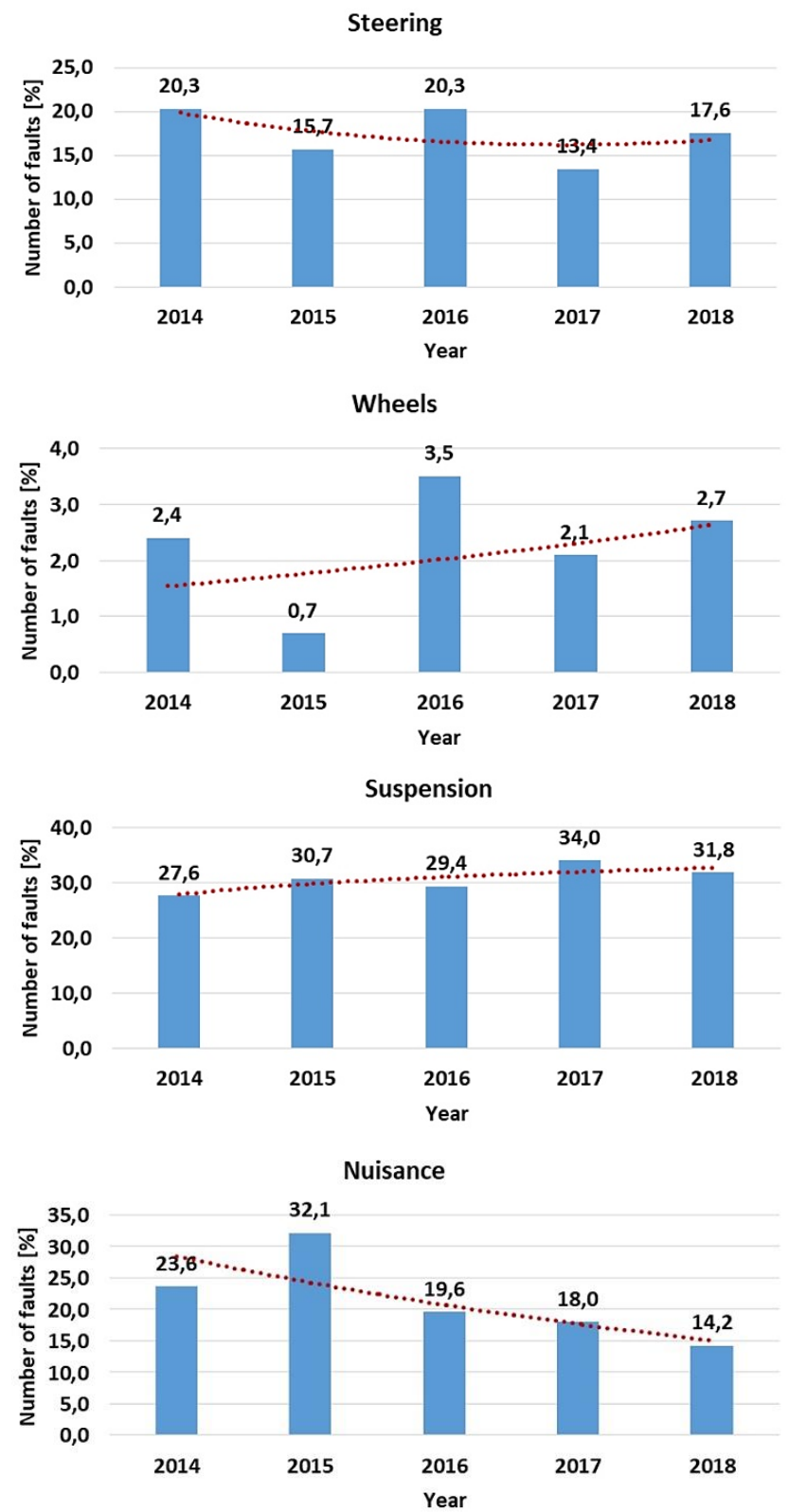

Fig. 4. The trends of change in the number of faults concerning the steering system, wheels, suspension and nuisance 
continued under the assumption that this trend would continue according to the data relation recorded in the last two years. The possibility of applying the trendline equations to the faults in the lighting system is distorted by the information from the year 2014 when definitely fewer faults occurred compared to the following years.
Therefore, for this group of faults the year 2014 was not considered (Fig. 5).

In order to obtain information related to the predicted number of faults of a given system in a given year, one should substitute the following years into the formulae (from 1 to 5 respectively $1=2014$ and $5=2018$ ). The formulae describing the

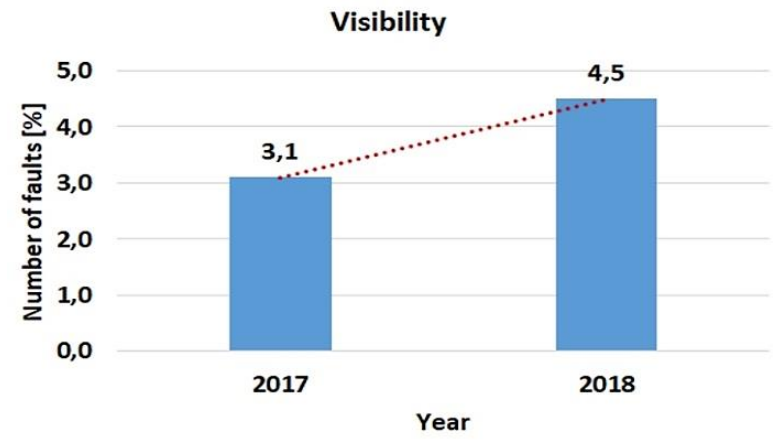

Lights and electrical equipment

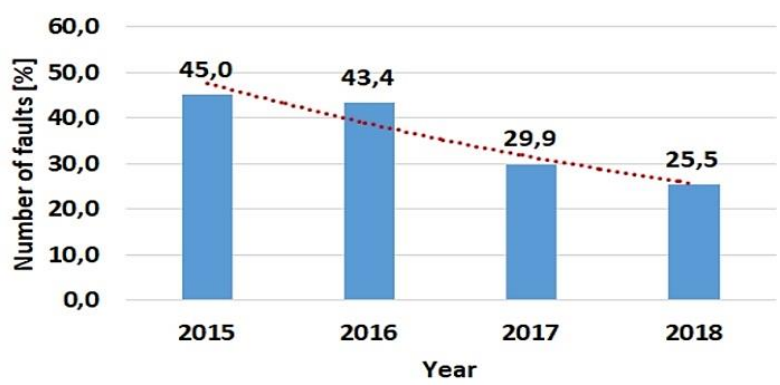

Fig. 5. The trends of change in the number of faults concerning visibility, lighting and electrical equipment

Table 3. Probability functions for the faults detected during inspections at Regional Vehicle Inspection Stations and the forecast for the year 2019

\begin{tabular}{|l|l|c|}
\hline Research subject & Function & $\mathbf{2 0 1 9}$ \\
\hline Brake system & $\mathrm{y}=-2.753 \mathrm{x}^{2}+17.867 \mathrm{x}+36.964$ & 45.1 \\
\hline Steering & $\mathrm{y}=0.4357 \mathrm{x}^{2}-3.3843 \mathrm{x}+22.82$ & $\mathbf{1 8 . 2}$ \\
\hline Visibility & $\mathrm{y}=1.4 \mathrm{x}+1.7$ & $\mathbf{5 . 9}$ \\
\hline Lights and electrical equipment & $\mathrm{y}=58.73 \mathrm{e}^{-0.208 \mathrm{x}}$ & 16.9 \\
\hline Axles & $\mathrm{y}=0.0429 \mathrm{x}^{2}-0.1371 \mathrm{x}+0.92$ & $\mathbf{1 . 6}$ \\
\hline Wheels & $\mathrm{y}=1.3513 \mathrm{e}^{0.1334 \mathrm{x}}$ & $\mathbf{3 . 0}$ \\
\hline Tyres & $\mathrm{y}=11.017 \mathrm{e}^{-0.07 x}$ & 7.2 \\
\hline Suspension & $\mathrm{y}=27.841 \mathrm{x}^{0.0999}$ & $\mathbf{3 3 . 3}$ \\
\hline Chassis and elements attached to it & $\mathrm{y}=2.0385 \ln (\mathrm{x})+15.988$ & 19.6 \\
\hline Nuisance & $\mathrm{y}=33.33 \mathrm{e}^{-0.159 x}$ & 8.6 \\
\hline
\end{tabular}


trendlines of specific faults are at the same time their probability functions. Table 3 contains a comparison of the formulae for the investigated systems. An example substitution for the year 2019 (substitute $\mathrm{x}$ with the value of 6 that corresponds to the year 2019, except for visibility, where the value of 3 has to be substituted and lighting, where the value is 5). The systems trending towards an increased share of detected faults were marked in bold (tab. 3).

\section{CONCLUSIONS}

Regional Vehicle Inspection Station statistics related to technical inspections resulting in a failure to obtain a road-legal status does not fully reflect reality because many stations have car workshops nearby. Hence, rather than fail an inspection, this causes many faulty vehicles to undergo a repair and be inspected anew. While such actions increase road safety, they also disrupt the true image of truck faults. In addition, the vehicle testing devices at the disposal of RVIS are not always in good technical condition. As shown in [11], the spread of measurement results, e.g. for braking force, can be as much as $20 \%$. However, the obtained data grant a view into the conditions of trucks on Polish roads. The probability of encountering a faulty truck (a fault that would require a repair) can be described with formula 1 . The information related to the type of fault occurring in the vehicles can be determined by applying the formulae from table 3 .

The results obtained are convergent with the data collected and analysed during road checks [12] conducted by the Road Transport Inspectorate forces. It shows that incidental road checks, similarly to periodic technical inspections, show a similar level of faults of the same systems and components.

Conducting the analysis revealed that:

1. The number of inspected trucks decreases by $8 \%$ per year.

2. The percentage of failing inspections (caused by faults) rose significantly.

3. The probability of occurrence of a given fault can be described with a function shown in table 3.

4. By using the indicated data relations, it was possible to calculate the probability of a vehicle fault in the following year 2019. For visibility, steering, axles, wheels and suspension, this probability increased, whereas for the remaining values it decreased.
The obtained knowledge about the probability of occurrence of specific types of faults can be used in practice to improve safety and prevent undesirable situations.

\section{SZACOWANIE PRAWDOPODOBIEŃSTWA} WYSTĄPIENIA USTERKI W POJEŹDZIE CIĘŻAROWYM

W artykule omówiono zagadnienia dotyczące wykrywania uszkodzeń przez diagnostów na Okręgowych Stacjach Kontroli Pojazdów w pojazdach ciężarowych. Dane do analiz pozyskano bezpośrednio z OSKP. Uzyskane wyniki przedstawiono w postaci wykresów słupkowych z wskazaniem trendów zmian w okresie od 2014r. do 2018r. Uzyskane trendy opisano równaniami i obliczono prawdopodobieństwo zaistnienia usterki $z$ analizowanej grupy układów. Dzięki uzyskanym zależnościom można szacować prawdopodobieństwo wystąpienia usterki pojazdu ciężarowego $w$ rocznym okresie eksploatacji.

Słowa kluczowe: usterka, pojazd ciężarowy, badanie techniczne, SKP

\section{BIBLIOGRAPHY}

[1] Filipczyk J., Makarova I., Belyaev E. (2015) "Analysis of periodical technical inspection system in automotive transport. The experiences of Poland and Russia". Transport Problems, Vol.10(4), p.121(8), ISSN: 1896-0596

[2] Robertson L. (1988) "(Weight x Speed) + Instability = Hazardous Trucks". American Journal of Public Health, May 1988, Vol.78(5), pp.486-7, ISSN: 00900036

[3] Van Voorhis S. (2018) "Steering in a better direction". ENR, Apr 23, Vol.280(12), p.18, ISSN: 08919526

[4] Sullivan J. M., FlannaganM. J. (2012) "Heavy trucks, conspicuity treatment, and the decline of collision risk in darkness". Journal of safety research, July 2012, Vol.43(3), pp.157-161. e-ISSN: 1879-1247; DOI: 10.1016/j.jsr.2012.05.005

[5] Police Headquarters, Road Traffic Bureau - Traffic Accidents in Poland in the year 2018, statistical data

[6] Hellwig Z:: Elementy rachunku prawdopodobieństwa i statystyki matematycznej. Wydawnictwo Naukowe PWN, Warszawa 1998

[7] Traffic Law Journal of Laws from the year 2017, pos. 128

[8] The Great Dictionary of the Polish Language (2019) www.wsjp.pl

[9] Journal of laws dated 10th of June 2015 item. 776 concerning the scope and methods of conducting technical inspection of vehicles and standards of documents used during the inspections

[10] www.cepik.gov.pl/statystyki

[11] Mańczak R., Ślaski, G. (2018) "The statistical dispersion of results of examination of selected vehicle subsystems tested in different technical inspection stations". IOP Conference Series: Materials Science and Engineering, 17 October 2018, Vol.421(3). ISSN: 17578981, e-ISSN: 1757899X, DOI: 10.1088/1757-899X/421/3/032017

[12] Kupiec A., Kupiec J., Jęsiek $Ł$. (2018) "Analiza przyczyn niesprawności pojazdów ciężarowych". Autobusy - Technika, Eksploatacja, Systemy Transportowe, nr 12; s. 115 - 120; ISSN 1509-5878; e- ISSN 2450-7725 